\title{
Ksenia Siadkowska
}

Politechnika Lubelska

k.siadkowska@wp.pl

\section{Prawne aspekty eksploatacji dronów}

\author{
Legal Issues for the Usage of Drones
}

\begin{abstract}
STRESZCZENIE
W ostatnich latach można zaobserwować rosnącą popularność bezzałogowych statków powietrznych, zwanych potocznie dronami. $Z$ tego względu ustawodawca znowelizował szereg aktów prawnych dotyczących obowiązków ciążących na operatorach takich modeli latających. W niniejszej pracy skupiono się na odpowiedzialności i ograniczeniach dla amatorskich użytkowników dronów oraz bezpieczeństwie osób postronnych. Poruszono także kwestie możliwości uzyskania świadectwa kwalifikacji operatora (UAVO) z uprawnieniami VLOS (lot w zasięgu wzroku), a także zagrożeń, jakie mogą zostać spowodowane przez niewłaściwą eksploatację modeli latających lub warunki zewnętrzne.
\end{abstract}

Słowa kluczowe: dron; bezzałogowy statek powietrzny; model latający; UAVO; VLOS

\section{WPROWADZENIE}

Od kilku lat wzrasta popularność bezzałogowych statków powietrznych wykorzystywanych przez osoby prywatne i przedsiębiorców. Najczęściej mamy do czynienia z określeniem „dron”. Zgodnie ze Stownikiem języka polskiego PWN jest to „bezzałogowy statek latający”1. Inną definicję, aczkolwiek niewykluczającą się z poprzednią, można znaleźć w Stowniku Oxford University Press, a mianowicie dron to m.in. ,zdalnie sterowany statek powietrzny lub pocisk” ${ }^{2}$. Z kolei według jednego z portali adresowanych do operatorów dronów jest to „bezzałogowy statek powietrzny, który może odbywać lot autonomiczny (samodziel-

\footnotetext{
${ }^{1}$ Dron, https://sjp.pwn.pl/sjp/dron;5574734.html [dostęp: 31.10.2017].

${ }^{2}$ https://en.oxforddictionaries.com/definition/drone [dostęp: 21.02.2017].
} 
nie, z użyciem autopilota lub innego systemu na pokładzie) lub zdalnie sterowany (kierowany przez operatora drona) poza zasięg wzroku"’3. Jest to nowe słowo w języku polskim i nawet kwestia odmiany nie została jeszcze ostatecznie uregulowana. Nie zmienia to faktu, że chociaż nie ma jednoznacznej definicji, to drona można kupić, bawić się nim, zarabiać za jego pomocą czy brać udział w zawodach sportowych.
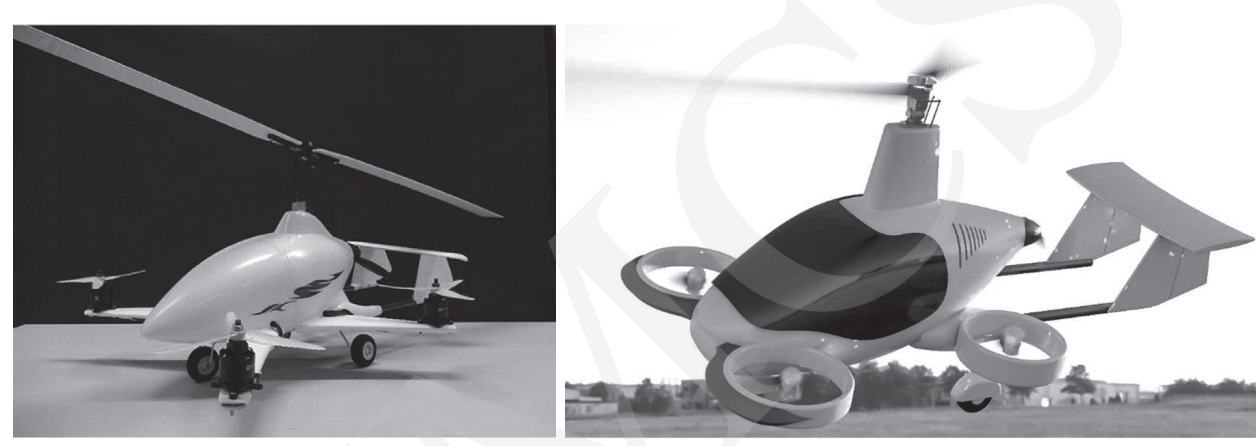

Fot. 1. Zdjęcie modelu bezzałogowego statku powietrznego projektowanego w Politechnice Lubelskiej (po lewej), symulacja komputerowa modelu w locie (po prawej). Autor fotografii i symulacji: Zbigniew Czyż

Rozwiązania dotychczas zarezerwowane dla zastosowań wojskowych obecnie są coraz częściej, chociaż nie w tak zaawansowanej technologicznie formie, narzędziem pracy fotografów ślubnych czy prezentem komunijnym. O ile osoby zawodowo zajmujące się wykorzystaniem dronów w ramach swojej działalności gospodarczej z racji konieczności posiadania określonych uprawnień zmuszane są nabywać wiedzę wymaganą egzaminem w celu uzyskania uprawnień, o tyle amator może stanowić solidne zagrożenie dla otoczenia. Regulacje prawne w tym zakresie nie są jednolite na terenie Unii Europejskiej, gdyż wprowadzenie ich leży w kompetencjach krajów członkowskich. Od 2015 r. prowadzone są prace w Parlamencie Europejskim mające na celu uporządkowanie tej tematyki. W 2016 r. na poziomie Unii Europejskiej została uregulowana kwestia lotu dronów w strefie kontrolowanej lotniska CTR ${ }^{4}$. Organizacja Międzynarodowego Lotnictwa Cywilnego (International Civil Aviation Organization - ICAO), odpowiedzialna za opracowywanie i wdrażanie międzynarodowych przepisów regulujących bezpieczeństwo ruchu lotniczego i ekonomię transportu lotniczego, jeszcze w 2014 r. stała na stanowisku, że modele latające i statki powietrzne używane

\footnotetext{
${ }^{3}$ www.swiatdronow.pl [dostęp: 31.10.2017].

${ }^{4}$ UAVO, Nowe rozporzadzenie unijne SERA C weszło w życie, http://uavo.com.pl/prawo/nowe-rozporzadzenie-unijne-sera-c-weszlo-zycie [dostęp: 31.10.2016].
} 
rekreacyjnie są poza jej zakresem działalności i leżą w gestii władz krajowych ${ }^{5}$. 23 marca 2015 r. przedstawiciele przemysłu lotniczego wezwali kraje członkowskie do współpracy z ICAO w celu stworzenia wspólnych globalnych standardów bezpieczeństwa w zakresie używania dronów oraz kwalifikacji operatorów ${ }^{6}$. ICAO, opracowując nowe standardy bezpieczeństwa, rozważa wsparcie dla krajów członkowskich w celu integracji dronów w przestrzeni powietrznej.

Celem niniejszego opracowania jest przedstawienie kwestii obowiązków i odpowiedzialności operatora drona w kontekście obowiązujących aktów prawnych. W artykule skupiono się na operatorach sportowych i rekreacyjnych, pokazano też drogę, jaką powinni pokonać, aby stać się operatorami komercyjnymi. Nie ulega wątpliwości, że użytkownicy dronów powinni wykazać się znajomością Prawa lotniczego, gdyż - jak pokazuje praktyka - nieodpowiedzialnie użytkowany sprzęt może prowadzić do spowodowania zagrożenia w ruchu powietrznym, a z nieświadomego operatora uczynić przestępcę.

W pracy wykorzystano metodę analizy krytycznej oraz analizy przypadków na podstawie obowiązujących aktów prawnych. Włączenie do przeprowadzonej analizy publikacji nienaukowych jest zabiegiem celowym, by zapewnić bardziej wszechstronne spojrzenie na aktualny stan wiedzy o dronach.

\section{DRONY W USTAWIE - PRAWO LOTNICZE}

Ustawa z dnia 3 lipca 2002 r. - Prawo lotnicze ${ }^{7}$ nie zawiera definicji terminu „dron”. Aby sprawnie poruszać się po aktach prawnych w celu ustalenia obowiązków ciążących na użytkownikach tego rodzaju statków powietrznych, należy zapoznać się z podstawowymi pojęciami związanymi z lotnictwem. Zgodnie z art. 2 pkt 1 Prawa lotniczego statkiem powietrznym jest urządzenie zdolne do unoszenia się w atmosferze na skutek oddziaływania powietrza innego niż oddziaływanie powietrza odbitego od podłoża. Dron, z racji swojego przeznaczenia i możliwości, jest pewnego rodzaju statkiem powietrznym, a mianowicie bezzałogowym. W związku z tym kolejnym ważnym zapisem dotyczącym operatorów dronów są art. 95 i 126 Prawa lotniczego, traktujące o świadectwie kwalifikacji oraz warunkach odbywania lotów bezzałogowych statków powietrznych.

W niniejszym opracowaniu skupiono się wyłącznie na bezzałogowych statkach powietrznych bez profesjonalnych urządzeń nawigacyjnych czy łącznościowych, użytkowanych w celach rekreacyjnych lub sportowych. W przypadku,

\footnotetext{
${ }^{5}$ R. Clarke, L. Bennett Moses, The regulation of civilian drones' impacts on public safety, “Computer Law \& Security Review" 2014, Vol. 30, s. 263-285.

${ }^{6}$ Staff Reports, ICAA \& FAA consider international drone standards, http://aircargoworld.com/ icao-faa-consider-international-drone-standards [dostęp: 03.11.2016].

${ }^{7}$ Dz.U. z 2002 r., nr 130, poz. 1112 z późn. zm.
} 
gdy operator jest zainteresowany komercyjnym wykorzystaniem drona, powinien uzyskać świadectwo kwalifikacji. Z uwagi na restrykcyjne ograniczenia dla amatorów omówiono także procedurę uzyskiwania świadectwa kwalifikacji.

\section{ŚWIADECTWO KWALIFIKACJI OPERATORA BEZZAŁOGOWEGO STATKU POWIETRZNEGO (UAVO)}

Ostatnio ogłoszonym dokumentem dotyczącym eksploatacji dronów w Rzeczypospolitej Polskiej jest rozporządzenie Ministra Infrastruktury i Budownictwa z dnia 19 września 2016 r. zmieniające rozporządzenie w sprawie świadectw kwalifikacji ${ }^{8}$. Jest ono dokumentem zmieniającym obowiązujące dotychczas rozporządzenie Ministra Transportu, Budownictwa i Gospodarki Morskiej z dnia 3 czerwca 2013 r. w sprawie świadectw kwalifikacji ${ }^{9}$. Aby móc lepiej zrozumieć obowiązujące przepisy, w wybranych miejscach zostaną przeanalizowane wprowadzone zmiany.

Przytoczone powyżej rozporządzenie z 2016 r. wprowadza do rozporządzenia z 2013 r. nowe pojęcie, jakim jest masa startowa, przez co rozumie się masę bezzałogowego statku powietrznego gotowego do lotu ( $\$ 3$ pkt 6a). Dotychczas funkcjonujące określenie dotyczyło maksymalnej masy startowej MTOM. Różnicę najłatwiej będzie wyjaśnić na przykładzie. Jeżeli dany dron może unieść maksymalnie $25 \mathrm{~kg}$ (w tym zawiera się jego masa własna i ładunek), a w czasie egzaminu ten sam statek powietrzny będzie ważył $4 \mathrm{~kg}$ (bez ładunku), to uprawnienia będą wydane na statek o maksymalnej masie $5 \mathrm{~kg}$. W praktyce oznacza to, że za możliwościami statku powietrznego nie muszą iść zdolności operatora, a lot statkiem powietrznym z obciążeniem i bez można porównać do jazdy samochodem osobowym z przyczepą campingową i bez niej - tu także mamy odrębną kategorię.

Zmianie uległ też zakres uprawnień wpisywanych do świadectwa kwalifikacji (załącznik nr 6 do rozporządzenia z dnia 3 czerwca 2013 r.). Jako uprawnienia podstawowe pozostawiono VLOS i BVLOS, czyli odpowiednio lot w zasięgu wzroku operatora i poza jego zasięgiem, natomiast kategoria statku powietrznego i jego maksymalna masa startowa są już uprawnieniami dodatkowymi. Istotne są tu górne graniczne wartości dla masy startowej, a wynoszą one do 5,25 i $150 \mathrm{~kg}$, podczas gdy dotychczas występowały ograniczenia dla maksymalnej masy startowej MTOM 2, 7, 25, 50 i powyżej $50 \mathrm{~kg}$. Zmiana w kwestii uprawnień podstawowych i dodatkowych ma znaczenie podczas szkolenia i podwyższania uprawnień np. na inną kategorię statku czy większą masę.

Rozporządzenie z dnia 3 czerwca 2013 r. określa także szczegółowe warunki i sposób prowadzenia szkolenia lotniczego. Zgodnie z § 29 ust. 2 szkolenie lotni-

\footnotetext{
${ }^{8}$ Dz.U. z 2016 r., poz. 1630, dalej jako: rozporządzenie z 2016 r.

${ }^{9}$ Dz.U. z 2013 r., poz. 664 z późn. zm., dalej jako: rozporządzenie z dnia 3 czerwca 2013 r.
} 
cze dla operatora bezzałogowych statków powietrznych używanych w celach innych niż rekreacyjne lub sportowe składa się ze szkolenia teoretycznego i praktycznego - na ziemi i w locie. Niezmiennie przewiduje się możliwość szkolenia do wykonywania lotów jedynie w zasięgu wzroku operatora VLOS metodą samokształcenia (§ 32 ust. 4).

Ważnym pojęciem jest świadectwo kwalifikacji operatora (UAVO). Dokument ten upoważnia do samodzielnego wykonywania czynności lotniczych w zakresie wynikającym z uprawnień wpisanych do tego świadectwa, czyli w tym przypadku jest to wspomniane wcześniej VLOS (lot w zasięgu wzroku). Zgodnie $\mathrm{z}$ nim w ramach szkolenia teoretycznego i praktycznego kandydat powinien zdobyć wiedzę i umiejętności zdefiniowane w załączniku nr 6 do rozporządzenia $\mathrm{z}$ dnia 3 czerwca 2013 r. w pkt 1.3.1.

Uzyskanie uprawnień do wykonywania lotów w zasięgu i poza zasięgiem wzroku BVLOS wymaga bardziej profesjonalnej wiedzy lotniczej. Powyższe przepisy teoretycznie obowiązują tylko osoby, które chcą wykorzystywać drony w sposób inny niż rekreacyjny i sportowy, czyli najczęściej komercyjny.

Zgodnie z tabelą wysokości opłat lotniczych zamieszczoną w obwieszczeniu Ministra Infrastruktury i Budownictwa z dnia 2 lutego 2016 r. w sprawie ogłoszenia obowiązujących w 2016 r. stawek opłat lotniczych ${ }^{10}$ koszt wydania świadectwa kwalifikacji po raz pierwszy lub jego przywrócenie oraz każde następne wydanie świadectwa kwalifikacji dla operatora bezzałogowego statku powietrznego używanego w celach innych niż rekreacyjne lub sportowe wynosi 43 zł, natomiast przeprowadzenie egzaminu praktycznego kandydatów na członków personelu lotniczego oraz członków personelu lotniczego na świadectwo kwalifikacji to koszt 105 zł. Jak podano w ogłoszeniu Prezesa Urzędu Lotnictwa Cywilnego z dnia 17 kwietnia 2016 r. w sprawie wyników „zapotrzebowania na wykonywanie niektórych czynności nadzoru i kontroli w zakresie wydawania świadectw kwalifikacji operatora bezzałogowego statku powietrznego UAVO", wybrano firmę RFgroup Kancelaria Ułatwień Lotniczych - Ryszard Foltynowicz z siedzibą w Warszawie. Jednostka ta została upoważniona do prowadzenia procedury wydawania świadectw kwalifikacji dla specjalności, o której mowa w art. 95 ust. 2 pkt 5a Prawa lotniczego, czyli dla operatora bezzałogowego statku powietrznego używanego w celach innych niż rekreacyjne lub sportowe ${ }^{11}$.

Czy nieznająca w ogóle przepisów lotniczych osoba, w której ręce trafi dron, nie stanowi zagrożenia dla otoczenia? Czy powyższe ograniczenia są wystarczające w celu zapewnienia bezpieczeństwa innym osobom, które znajdą się w strefie oddziaływania dronów? Ustawodawca wprowadził dla operatorów rekreacyjnych

\footnotetext{
${ }^{10}$ M.P. 2016, poz. 154.

${ }^{11}$ Prezes ULC, Ogłoszenie Prezesa ULC, http://ulc.gov.pl/_download/wiadomosci/04_2016/ ogloszenie-uavo.pdf [dostęp: 31.10.2016].
} 
i sportowych pewne dość restrykcyjne ograniczenia, zwłaszcza w kwestii terenu, w którym loty mogą być wykonywane, z których nie wszystkie obowiązują posiadaczy świadectw kwalifikacji operatora UAVO.

\section{WARUNKI I WYMAGANIA DOTYCZĄCE UŻYWANIA DRONÓW}

Kolejnym istotnym aktem prawnym wprowadzonym w 2016 r. jest rozporządzenie Ministra Infrastruktury i Budownictwa z dnia 8 sierpnia 2016 r. zmieniające rozporządzenie $\mathrm{w}$ sprawie wyłączenia zastosowania niektórych przepisów ustawy - Prawo lotnicze do niektórych rodzajów statków powietrznych oraz określenia warunków i wymagań dotyczących używania tych statków ${ }^{12}$. Zmienionym aktem jest rozporządzenie Ministra Transportu, Budownictwa i Gospodarki Morskiej z dnia 26 marca 2013 r. w sprawie wyłączenia zastosowania niektórych przepisów ustawy - Prawo lotnicze do niektórych rodzajów statków powietrznych oraz określenia warunków i wymagań dotyczących używania tych statków ${ }^{13}$. Przywołane dokumenty dosyć precyzyjnie określają prawa i obowiązki operatorów dronów. Sprecyzowano rodzaje statków powietrznych, które są wyłączone ze stosowania niektórych przepisów Prawa lotniczego oraz szczegółowe warunki i wymagania dotyczące używania objętych rozporządzeniem statków powietrznych, w tym zwłaszcza ( $§ 2$ ust. 1 pkt 1 lit. d i f) bezzałogowych statków powietrznych o masie startowej nie większej niż $150 \mathrm{~kg}$, używanych wyłącznie w celach rekreacyjnych lub sportowych, oraz bezzałogowych statków powietrznych o masie startowej nie większej niż $25 \mathrm{~kg}$, używanych w celach innych niż rekreacyjne lub sportowe. Ponadto wyłącza się zastosowanie do bezzałogowych statków powietrznych o masie startowej nie większej niż $150 \mathrm{~kg}$, używanych wyłącznie w operacjach w zasięgu widoczności wzrokowej VLOS, przepisów art. 126 ust. 2-5 ustawy Prawo lotnicze, z uwzględnieniem przepisów określonych w załącznikach nr 6 i $6 a$ do rozporządzenia (§ 2 ust. 5). Zapis ten zwiększa możliwości użytkowania dronów, zwalniając operatorów ze spełnienia warunków Prawa lotniczego (np. o zgłaszaniu planów lotu i konieczności posiadania urządzeń nawigacyjnych), ale pozostałe zapisy omawianego rozporządzenia nie pozostawiają dowolności w tym zakresie. W związku z powyższym rozporządzenie (§ 4 ust. 1 pkt 6 i 7) określa szczegółowe warunki i wymagania dotyczące m.in. bezzałogowych statków powietrznych o masie startowej nie większej niż $150 \mathrm{~kg}$, używanych wyłącznie w operacjach w zasięgu widoczności wzrokowej VLOS, zarówno w celach rekreacyjnych, jak i sportowych oraz innych. Przywołane akty prawne konsekwentnie nie definiują pojęcia „dron”, natomiast w znowelizowanym załączniku $\mathrm{nr} 6^{6}$ uproszczono nieco nazewnictwo i bezzałogowe statki

\footnotetext{
${ }^{12}$ Dz.U. z 2016 r., poz. 1317.

${ }^{13}$ Dz.U. z 2013 r., poz. 440 z późn. zm.
} 
powietrzne o masie startowej nie większej niż $150 \mathrm{~kg}$, używane wyłącznie w operacjach w zasięgu widoczności wzrokowej VLOS w celach rekreacyjnych lub sportowych definiowane są jako modele latające. Ponieważ znowelizowany załącznik $n r 6 a^{6}$ dotyczy celów innych niż sportowe i rekreacyjne, nie zostanie on w niniejszej pracy szczegółowo omówiony, gdyż właściwie dotyczy głównie działalności gospodarczej i związany jest z posiadaniem świadectwa kwalifikacji operatora UAVO, co zostało już częściowo omówione i jest dedykowane dla osób zajmujących się wykorzystaniem dronów głównie w celach komercyjnych. Ze względu na to, że drony są urządzeniami coraz powszechniej dostępnymi, w dalszej części pracy skupiono się na użytkownikach rekreacyjnych oraz sportowych i odpowiedzialności, z której osoby nieinteresujące się lotnictwem nie zdają sobie sprawy.

Zgodnie z załącznikiem nr 6 ust. 3 odpowiedzialność operatora, czyli osoby zdalnie pilotującej model latający, jest sprowadzona przede wszystkim do zachowania szczególnej ostrożności oraz ponoszenia odpowiedzialności za poprawność lotu i stan techniczny modelu. Pozornie ogólne zapisy mogą uczynić przestępcę z nieświadomego użytkownika modelu latającego. Kodeks karny ${ }^{14}$ za sprowadzenie niebezpieczeństwa katastrofy $\mathrm{w}$ ruchu powietrznym przewiduje karę pozbawienia wolności od 6 miesięcy do lat 8 , a przy działaniu nieumyślnym - do lat 3 (art. 174), zaś sprowadzenie takiej katastrofy zagrażającej życiu lub zdrowiu wielu osób albo mieniu w wielkich rozmiarach może oznaczać karę pozbawienia wolności od roku do lat 10 . Wbrew pozorom bezpieczeństwo obserwatorów oraz ruchu powietrznego może zostać bardzo łatwo naruszone z wykorzystaniem właśnie dronów, wystarczy podarować nieletniemu mieszkającemu niedaleko lotniska prezent w postaci kilogramowego drona. Ust. 4 załącznika nr 6 precyzyjnie określa zasady wykonywania lotów, w tym bezpieczne odległości w każdej fazie lotu i konieczność utrzymania kontaktu wzrokowego. Może nie wprost, ale z powyższych zapisów wynika, że w praktyce rekreacyjny lub sportowy operator drona może go użytkować przykładowo tylko na łące, oczywiście z zachowaniem bezpiecznych odległości. Kolejne zasady zawarte we wzmiankowanym ustępie jeszcze bardziej ograniczają zgodne z prawem użytkowanie modeli latających, m.in. ust. $4.1 \mathrm{pkt} 5$ : ,[...] uwzględniając warunki meteorologiczne, strukturę i klasyfikację przestrzeni powietrznej oraz informacje o ograniczeniach w ruchu lotniczym". O ile amatorski użytkownik modelu latającego poradzi sobie z uwzględnieniem warunków meteorologicznych, o tyle warto zauważyć, że od wspomnianego amatora wymagana jest profesjonalna wiedza o przestrzeni powietrznej. Dlaczego profesjonalna? W dużym uproszczeniu można przyjąć, że przestrzeń powietrzna podzielona jest na strefy, w których warunki lotu określa-

${ }^{14}$ Ustawa z dnia 6 czerwca 1997 r. - Kodeks karny (t.j. Dz.U. z 2016 r., nr 0, poz. 1137 z późn. zm.). 
ją zarządzający daną strefą, co zazwyczaj wiąże się też z wydaniem zgody na lot. Przykładowo w strefie kontrolowanej lotniska CTR (Control Zone) warunki określa instytucja zapewniająca służbę ruchu lotniczego. Podobnym restrykcjom podlegają też strefy: ruchu lotniskowego ATZ (Aerodrome Traffic Zone), niebezpieczna D (Danger Area), kontrolowana lotniska wojskowego MCTR (Military Control Area), ruchu lotniskowego lotniska wojskowego MATZ (Military Aerodrome Traffic Zone), o ograniczonym ruchu lotniczym R (Restricted Area, tu: dotyczy parków narodowych), zakazana P (Prohibited Area) oraz identyfikacji obrony powietrznej ADIZ (Air Defense Identification Zone).

Idąc dalej tropem, gdzie przykładowo można latać dronem, operator ma obowiązek sprawdzić, czy łąka, nad którą chce wykonać lot, nie znajduje się np. na terenie parku narodowego lub w strefie o ograniczonym ruchu lotniczym. Jeśli chce taki lot wykonać, musi uzyskać stosowne zgody zarządzającego strefą. Gdyby ktoś chciał eksploatować drony nad centrum Warszawy na zachód od Wisły (lub $\mathrm{w}$ innej strefie z ograniczeniami związanymi z bliskością lotniska; w Polsce istnieje 14 lotnisk komunikacyjnych z ograniczeniami w postaci strefy CTR), powinien uzyskać zgodę Polskiej Agencji Żeglugi Powietrznej minimum 5 dni przed planowanym lotem w celu określenia możliwości i warunków wykonania lotów.

Niezależnie od planowanej wysokości lotu, czy to na wysokości koron drzew czy kilkuset metrów, taka zgoda jest wymagana w strefach kontrolowanych dla każdego operatora omawianych modeli latających. Istotne jest, czy lot odbywa się w budynku czy na zewnątrz. W pierwszym przypadku wymagana jest tylko zgoda zarządzającego obiektem budowlanym. Ustawodawca przewidział jednak kolejny ,wyjątek od wyjątku” dla modeli latających o masie startowej mniejszej niż $0,6 \mathrm{~kg}$ (ust. 4.4 załącznika $\mathrm{nr}$ 6). Takimi statkami powietrznymi można latać, nie zachowując odległości 30 i $100 \mathrm{~m}$ od zabudowy i ludzi. Ponadto w strefach CTR, ATZ, P i ADIZ powyższe ograniczenia dla małych modeli (do $0,6 \mathrm{~kg}$ ) zmieniają postać i nie ma konieczności uzyskiwania zgód, gdy odległość od granicy lotniska jest większa niż $1 \mathrm{~km}$ lub lot odbywa się poza terenem obiektów chronionych przez strefę P do wysokości nie większej niż $30 \mathrm{~m}$ lub do wysokości najwyższej przeszkody, jak drzewa lub obiekty budowlane znajdujące się w promieniu do $100 \mathrm{~m}$ od operatora.

Pojawia się także kolejny wyjątek dla wykonywania lotów modelami latającymi o masie startowej nie większej niż $25 \mathrm{~kg}$, zgodnie z którym zgody odpowiednich organów nie są potrzebne w strefie CTR i ATZ, jeżeli dron nie znajdzie się w odległości mniejszej niż $6 \mathrm{~km}$ od granicy lotniska i do wysokości nie większej niż $100 \mathrm{~m}$ nad poziomem terenu. To znaczy, że operator drona powinien najpierw sprawdzić, czy teren (łąka), nad którym chce latać, nie znajduje się w strefie chronionej Prawem lotniczym. W tym celu powstały już aplikacje na urządzenia mobilne, które ułatwiają użytkownikom orientację w przepisach i w terenie. 
W załączniku nr 6 ust. 4.6 wprowadzone jest jeszcze jedno ograniczenie, od którego już nie ma wyjątków, a mianowicie dotyczące niemożności wykonywania lotów nad terenami zamkniętymi, obiektami jądrowymi i określonymi tam obszarami, obiektami i urządzeniami. Zapis ten powinien być właściwie punktem wyjścia dla każdego operatora drona, gdyż wymaga od potencjalnego użytkownika znajomości przytoczonych dokumentów. Stosunkowo oczywiste wydaje się ograniczenie dla terenów zamkniętych ważnych dla obronności i bezpieczeństwa kraju czy obiektów jądrowych. Dodatkowo dochodzą do tego m.in. zakłady produkcji specjalnej, zakłady z urządzeniami i sprzętem wojskowym (produkcja, remont, magazynowanie), magazyny rezerw strategicznych, zakłady związane z wydobyciem surowców mineralnych, porty morskie i lotnicze, ale także banki i przedsiębiorstwa wytwarzające, przechowujące bądź transportujące wartości pieniężne w znacznych ilościach. Ponadto przed sportowymi i rekreacyjnymi operatorami dronów zamknięte są obszary z elektrowniami, ciepłowniami, ujęciami wody, wodociągi i oczyszczalnie ścieków, okolice istotnych rurociągów paliwowych, linii energetycznych i telekomunikacyjnych. Do tego dochodzą zakłady o unikalnej produkcji gospodarczej, obiekty i urządzenia telekomunikacyjne, pocztowe oraz telewizyjne i radiowe, a także muzea i inne obiekty, w których zgromadzone są dobra kultury narodowej, archiwa państwowe i infrastruktura krytyczna. Szczegółowy wykaz takich obszarów prowadzą wojewodowie, jednak ta ewidencja ma charakter poufny ${ }^{15}$. Podsumowując, operator drona, latający rekreacyjnie lub sportowo, bez świadectwa kwalifikacji UAVO może zgodnie z prawem latać nad otwartą łąką z dala m.in. od lotnisk, zabudowań, linii energetycznych i podwórka sąsiada.

Można przypuszczać, że ustawodawca, ustalając takie restrykcyjne przepisy, oprócz bezpieczeństwa obywateli, miał na celu również skłonienie rekreacyjnych i sportowych operatorów dronów do uzyskiwania uprawnień UAVO, dzięki czemu siłą rzeczy nabędą oni pewną wiedzę lotniczą i będą stanowić mniejsze zagrożenie. Nie sposób w tym miejscu nie odwołać się do wzmiankowanego wcześniej załącznika $6 a^{6}$, który dotyczy lotów innych niż rekreacyjne i sportowe. Interesujący jest fakt, że po uzyskaniu świadectwa kwalifikacji operatora UAVO można wykonywać loty dronami w „bezpiecznej odległości poziomej od osób, mienia, pojazdów, obiektów budowlanych lub innych użytkowników przestrzeni powietrznej niebędących w dyspozycji lub pod kontrolą operatora na wypadek awarii lub utraty kontroli nad bezzałogowym statkiem powietrznym" (ust. 4.1 pkt 3). Precyzyjne ograniczenia lub ich brak pojawiają się tylko dla modeli lekkich (do $0,6 \mathrm{~kg}$ ) oraz modeli do $25 \mathrm{~kg} \mathrm{w}$ sytuacji bliskości lotniska i są one tożsame z tymi, które obowiązują operatorów bez świadectwa kwalifikacji. Ponadto nad terenami zamkniętymi, obiektami jądrowymi i innymi terenami niedostępnymi

${ }^{15}$ Art. 5 pkt 5 ustawy z dnia 22 sierpnia 1997 r. o ochronie osób i mienia (Dz.U. z 1997 r., nr 114, poz. 740). 
dla operatorów rekreacyjnych i sportowych, omówionymi powyżej, ograniczeniem jest ,zgoda lub potrzeby zarządzającego danym terenem, obiektem, obszarem lub urządzeniem" (ust. 4.1 pkt 12).

\section{ZAGROŻENIA I WYPADKI Z UDZIAŁEM DRONÓW}

Dla amatorów dronów studiowanie aktów prawnych przypuszczalnie nie należy do interesujących zajęć. Internet dostarcza jednak wizualizacji zagrożeń, jakie niesie ze sobą eksploatacja modeli latających. Do tych najbardziej spektakularnych można zaliczyć upadek drona tuż obok zawodnika podczas nagrywania alpejskiego Pucharu Świata 2015 i decyzję o rezygnacji z tego sposobu rejestrowania zawodów ${ }^{16}$. Takie sytuacje pokazują, że nawet profesjonalnie wykorzystywany sprzęt i wyszkolony operator nie mają wpływu w sytuacji zakłóceń sygnału, podmuchów wiatru czy zawodności samej elektroniki, czego przejawem może być szybsze rozładowywanie się baterii na mrozie. Znane są przypadki dronów zaatakowanych przez ptaki, zderzenia z budynkami i uderzenia w filmowanych w czasie ślubu ludzi ${ }^{17}$.

Do ciekawego zdarzenia doszło na początku czerwca 2015 r., gdy podczas koncertu Enrique Iglesiasa w Meksyku doszło do krwawego kontaktu jego dłoni z dronem filmującym wydarzenie ${ }^{18}$. Wypadek ten znajduje odzwierciedlenie chociażby w narzędziu Google Trendy ${ }^{19}$ jako największy pik na wykresie przedstawiającym zainteresowanie w ujęciu czasowym na przestrzeni ostatnich 5 lat wyszukiwaniem słowa „dron” przy uwzględnieniu dostępnych opcji: cały świat, wyszukiwarka Google. Ponadto łatwo zauważyć trend wzrastający na rys. 1.

Według Federalnej Administracji Lotnictwa FAA w 2014 r. w Stanach Zjednoczonych zanotowano 238 spotkań pilotów z dronami. W 2015 r. tylko do sierpnia było 650 takich przypadków ${ }^{20}$. Hasło „dron wypadek” wpisane w wyszukiwarce www.google.pl ${ }^{21}$ wskazuje na przestrzeni ostatnich lat na wykładniczy wzrost za-

${ }^{16}$ M. Połowianiuk, Wideo dnia: po tym incydencie drony przestaja nagrywać Puchar Świata w narciarstwie alpejskim, www.spidersweb.p1/2015/12/upadek-drona-puchar-swiata.html [dostęp: 21.10.2017].

${ }^{17}$ Ł. Michalik, 9 wypadków z dronami. Kompromitacja wojska, atak ptaków i znokautowana panna młoda, https://gadzetomania.pl/1590,9-wypadkow-z-dronami-kompromitacja-wojska-atakptakow-i-znokautowana-panna-mloda,all [dostęp: 21.10.2017].

${ }^{18}$ Zakrwawiona dłoń Iglesiasa. Na koncercie ,, chwycit drona”, www.tvn24.p1/wiadomosci-zeswiata,2/dron-poranil-palce-enrique-iglesiasowi,547475.html [dostęp: 21.10.2017].

${ }^{19}$ www.google.com/trends/explore?q=dron [dostęp: 21.10.2017].

${ }^{20} \mathrm{M}$. Maj, Dron o mato nie trafit narciarza $w$ czasie mistrzostw, http://di.com.pl/dron-o-malonie-trafil-narciarza-w-czasie-mistrzostw-przybywa-takich-i-gorszych-wypadkow-54040 [dostęp: 21.10.2017].

${ }^{21}$ Data wpisania hasła: 21 października $2016 \mathrm{r}$. 
Pobrane z czasopisma Studia Iuridica Lublinensia http://studiaiuridica.umcs.pl Data: 26/04/2023 07:25:16

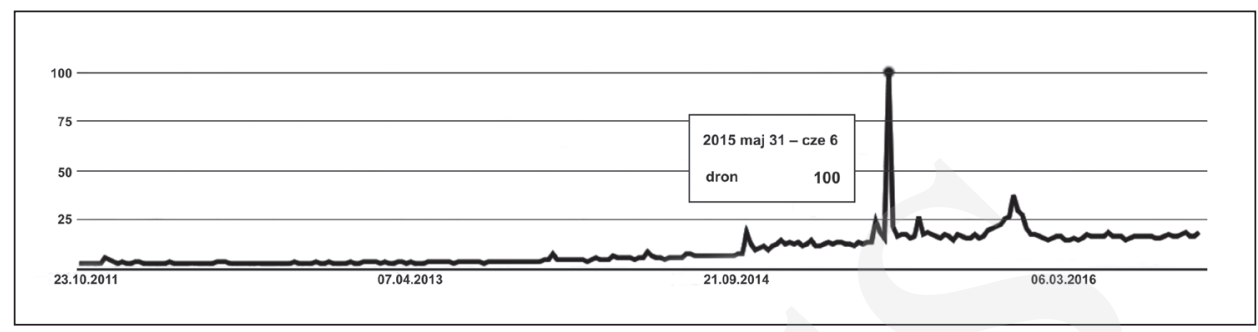

Rys. 1. Zainteresowanie w ujęciu czasowym na przestrzeni 5 lat wyszukiwaniem słowa „dron” z wykorzystaniem narzędzia Google Trendy

Źródło: www.google.com/trends/explore?q=dron [dostęp: 21.10.2017].

interesowania, co przedstawiono na rys. 2. Do aproksymacji wzrostu liczby wyników dla wskazanego słowa kluczowego wykorzystano wielomian drugiego stopnia z zastosowaniem metody najmniejszych kwadratów o postaci:

$$
Q(x)=999,285 * x^{2}-4020417,246 x^{1}+4043831517,986 * x^{0}
$$

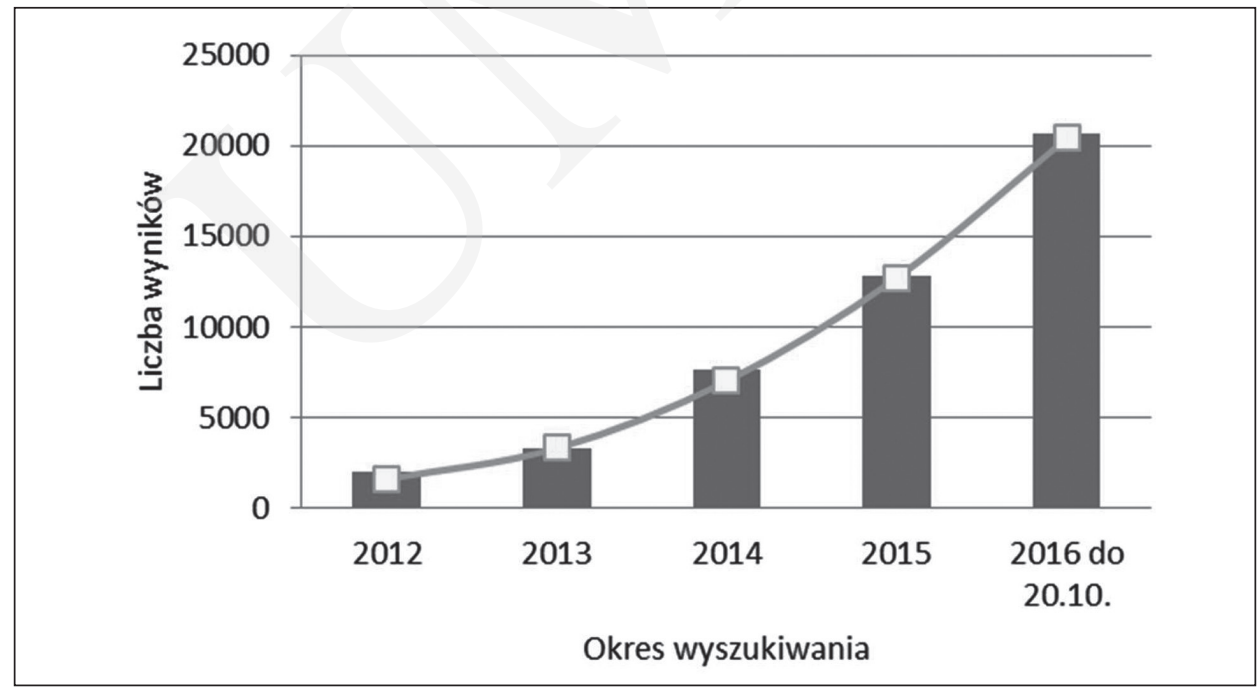

Rys. 2. Zainteresowanie wyszukiwaniem frazy „dron wypadek” w latach 2012-2016 z wykorzystaniem www.google.pl wraz z aproksymacją

Źródło: opracowanie własne.

Interesującą analizę uregulowań prawnych dla cywilnych dronów przeprowadził R. Clarke ${ }^{22}$. Jako stosunkowo nowy rodzaj zagrożenia wskazał naruszenie prywatności oraz wpływ na bezpieczeństwo publiczne. O takim incydencie z udziałem drona poinformował w 2014 r. były minister spraw zagranicznych.

${ }^{22} \mathrm{R}$. Clarke, The regulation of civilian drones' impacts on behavioural privacy, "Computer Law \& Security Review" 2014, Vol. 30, s. 286-305. 
Dron jednego z serwisów informacyjnych nagrał film pt. Zobacz majątek Sikorskiego i opublikował na stronie internetowej, w związku z czym zainteresowany złożył doniesienie do prokuratury w sprawie publikacji nagrania oraz za naruszenie prywatności domu przy pomocy drona ${ }^{23}$. W 2016 r. nagranie nadal było dostępne we wspomnianym serwisie informacyjnym.

\section{PODSUMOWANIE}

Rynek bezzałogowych statków powietrznych rozwija się z dynamiką znacznie większą niż przepisy regulujące zasady ich eksploatacji. W niniejszym opracowaniu przedstawiono analizę obowiązujących w Polsce aktów prawnych oraz zagrożenia wynikające z eksploatacji dronów. Skupiono się na wymaganiach stawianych przed operatorami bezzałogowych statków powietrznych oraz konsekwencjach ignorowania kwestii bezpieczeństwa zarówno przez operatorów, jak i obserwatorów znajdujących się w strefie oddziaływania modeli latających. Ponadto został omówiony zakres obowiązków i odpowiedzialności operatora bezzałogowego statku powietrznego wykorzystywanego w celach sportowych i rekreacyjnych oraz warunki uzyskania uprawnień umożliwiających loty komercyjne. Wskazano też na konieczność posiadania profesjonalnej wiedzy w celu bezpiecznego użytkowania bezzałogowych statków powietrznych oraz czynniki, na które operator nie ma wpływu, a które mogą sprowadzić zagrożenie dla otoczenia. Dodatkowo przybliżono definicje i zakres uprawnień oraz restrykcyjne ograniczenia dla operatorów rekreacyjnych i sportowych, a także warunki i bezpieczne odległości, w jakich powinien odbywać się lot bezzałogowym statkiem powietrznym, w tym znajomość przez operatora klasyfikacji przestrzeni powietrznej czy ograniczeń występujących w ruchu lotniczym. Przytoczono wybrane przykłady wypadków z udziałem bezzałogowych statków powietrznych i dokonano analizy trendów.

\section{BIBLIOGRAFIA}

Clarke R., The regulation of civilian drones' impacts on behavioural privacy, "Computer Law \& Security Review" 2014, Vol. 30.

Clarke R., Bennett Moses L., The regulation of civilian drones' impacts on public safety, "Computer Law \& Security Review” 2014, Vol. 30.

Dron, https://sjp.pwn.pl/sjp/dron;5574734.html [dostęp: 31.10.2017].

Dron „Faktu nad posiadłościa Sikorskiego”, www.tvn24.pl/wiadomosci-z-kraju,3/dron-faktu-nadposiadloscia-sikorskiego-szef-msz-zawiadamia-prokurature,449770.html [dostęp: 03.11.2017].

${ }^{23}$ Dron „Faktu nad posiadtościa Sikorskiego”, www.tvn24.pl/wiadomosci-z-kraju,3/dron-faktu-nad-posiadloscia-sikorskiego-szef-msz-zawiadamia-prokurature,449770.html [dostęp: 03.11.2017]. 
https://en.oxforddictionaries.com/definition/drone [dostęp: 21.02.2017].

Maj M., Dron o mato nie trafit narciarza $w$ czasie mistrzostw, http://di.com.pl/dron-o-malo-nietrafil-narciarza-w-czasie-mistrzostw-przybywa-takich-i-gorszych-wypadkow-54040 [dostęp: 21.10.2017].

Michalik Ł., 9 wypadków z dronami. Kompromitacja wojska, atak ptaków i znokautowana panna mloda, https://gadzetomania.p1/1590,9-wypadkow-z-dronami-kompromitacja-wojska-atakptakow-i-znokautowana-panna-mloda,all [dostęp: 21.10.2017].

Obwieszczenie Ministra Infrastruktury i Budownictwa z dnia 2 lutego 2016 r. w sprawie ogłoszenia obowiązujących w 2016 r. stawek opłat lotniczych (M.P. 2016, poz. 154).

Połowianiuk M., Wideo dnia: po tym incydencie drony przestają nagrywać Puchar Świata w narciarstwie alpejskim, www.spidersweb.pl/2015/12/upadek-drona-puchar-swiata.html [dostęp: 21.10.2017].

Prezes ULC, Ogłoszenie Prezesa ULC, http://ulc.gov.pl/_download/wiadomosci/04_2016/ogloszenie-uavo.pdf [dostęp: 31.10.2016].

Rozporządzenie Ministra Infrastruktury i Budownictwa z dnia 8 sierpnia 2016 r. zmieniające rozporządzenie w sprawie wyłączenia zastosowania niektórych przepisów ustawy - Prawo lotnicze do niektórych rodzajów statków powietrznych oraz określenia warunków i wymagań dotyczących używania tych statków (Dz.U. z 2016 r., poz. 1317).

Rozporządzenie Ministra Infrastruktury i Budownictwa z dnia 19 września 2016 r. zmieniające rozporządzenie w sprawie świadectw kwalifikacji (Dz.U. z 2016 r., poz. 1630).

Rozporządzenie Ministra Transportu, Budownictwa i Gospodarki Morskiej z dnia 26 marca 2013 r. w sprawie wyłączenia zastosowania niektórych przepisów ustawy - Prawo lotnicze do niektórych rodzajów statków powietrznych oraz określenia warunków i wymagań dotyczących używania tych statków (Dz.U. z 2013 r., poz. 440 z późn. zm.).

Rozporządzenie Ministra Transportu, Budownictwa i Gospodarki Morskiej z dnia 3 czerwca 2013 r. w sprawie świadectw kwalifikacji (Dz.U. z 2013 r., poz. 664 z późn. zm.).

Staff Reports, ICAA \& FAA consider international drone standards, http://aircargoworld.com/icao-faa-consider-international-drone-standards [dostęp: 03.11.2016].

UAVO, Nowe rozporzadzenie unijne SERA C weszło $w$ życie, http://uavo.com.pl/prawo/nowe-rozporzadzenie-unijne-sera-c-weszlo-zycie [dostęp: 31.10.2016].

Ustawa z dnia 6 czerwca 1997 r. - Kodeks karny (t.j. Dz.U. z 2016 r., nr 0, poz. 1137 z późn. zm.). Ustawa z dnia 22 sierpnia 1997 r. o ochronie osób i mienia (Dz.U. z 1997 r., nr 114, poz. 740).

Ustawa z dnia 3 lipca 2002 r. - Prawo lotnicze (Dz.U. z 2002 r., nr 130, poz. 1112 z późn. zm.). www.google.com/trends/explore?q=dron [dostęp: 21.10.2017].

www.swiatdronow.pl [dostęp: 31.10.2017].

Zakrwawiona dłoń Iglesiasa. Na koncercie „,chwycił drona”, www.tvn24.pl/wiadomosci-ze-swiata,2/dron-poranil-palce-enrique-iglesiasowi,547475.html [dostęp: 21.10.2017]. 
Pobrane z czasopisma Studia Iuridica Lublinensia http://studiaiuridica.umes.pl Data: 26/04/2023 07:25:16

\section{SUMMARY}

In the last years, we have seen the increasing popularity of unmanned aerial vehicles, commonly called drones. For this reason, the legislator has amended a number of legal acts on obligations imposed on operators of such flying models. This paper focuses on responsibilities and limitations of amateur users of drones and safety of third parties. The issues of obtaining an Unmanned Aerial Vehicle Operator (UAVO) Certificate with Visual Line of Sight (VLOS) qualifications as well as threats that may result from an incorrect use of flying models or external conditions are also discussed here.

Keywords: drone; unmanned aerial vehicle; flying model; UAVO; VLOS 